\title{
Colorectal Cancer pN1b TNM Finding v7
}

National Cancer Institute

\section{Source}

National Cancer Institute. Colorectal Cancer pN1b TNM Finding v7. NCI Thesaurus. Code C89951.

Colorectal cancer with metastasis in 2-3 regional lymph nodes. (from AJCC 7th Ed.) 